\title{
A Model-Based Investigation of Learner Attitude towards Recently Introduced Classroom Technology
}

\author{
Nick-Naser Manochehri \\ Accounting and Information \\ Systems Department \\ Khurram Sharif \\ Management \& Marketing \\ Department \\ College of Business \& Economics, Qatar University - Qatar \\ nickm@qu.edu.qa \\ ksharif@qu.edu.qa
}

\section{Executive Summary}

The major aim of this study was to uncover the influence of recently introduced classroom technology on a student's learning attitude. Research was conducted in a Gulf Cooperation Council (GCC) region university where classroom technology was being implemented for the first time. Hence specific attention was being given to the careful management of this educational innovation. The study was a part of this initiative where emphases were on relevance and appropriateness of technology to set-up and create user-driven learning and teaching environment.

The antecedents that were considered relevant in the early implementation phase (taken as first year of classroom technology implementation) were experience with Information and Communication Technologies (ICTs), enhanced communications, learner independence, and ease of technology use. The selected antecedents were socially, culturally, and educationally suitable as they were extracted from the students themselves by involving them in exploratory research. The original concept for this research was derived from the Technology Acceptance Model (TAM) which has been a source of numerous studies exploring user attitude towards technology.

In general, data analysis involved descriptive (to include mean and standard deviation) and reliability analysis (based on Cronbach's $\alpha$ ). This was followed by bivariate correlation giving evidence of discriminant validity. As all the items were developed by the authors, exploratory factor analysis was conducted to establish their fitness for research use. Finally multiple regression analysis was carried out to test the modular pathways.

The study outcome implied that use of classroom technologies, in the introduction stage, does increase with the degree of perceived and encountered ease of use and extended capacity for self-

Material published as part of this publication, either on-line or in print, is copyrighted by the Informing Science Institute. Permission to make digital or paper copy of part or all of these works for personal or classroom use is granted without fee provided that the copies are not made or distributed for profit or commercial advantage AND that copies 1) bear this notice in full and 2) give the full citation on the first page. It is permissible to abstract these works so long as credit is given. To copy in all other cases or to republish or to post on a server or to redistribute to lists requires specific permission and payment of a fee. Contact 0HPublisher@InformingScience.org to request redistribution permission. directed learning by utilizing channels

that enhance communication and information flows. Therefore, the flexibility to control and manage the speed and scope of learning through technology was seen to be having a conducive and positive impact on learner attitude. However prior experience of ICTs did not impact the learner attitude. Finally, practical implications for the implementation of classroom technologies were 
provided and avenues for future research were outlined.

Keywords: Classroom technology, learner attitude and independence, enhanced communications, ICT, TAM.

\section{Introduction}

Recent technological advancements have provided educators and learners with new tools to support in-class instruction and coursework. Hence integrating technology into classrooms is a growing initiative that is becoming an important and growing part of educational culture and university life (Bratina, Hayes, \& Blumsack, 2002; Wiley 2001). For instance, California's educational budget provided a total of $\$ 433$ million in 2003 to increase the use of technology in schools and universities. In 2008 the United States provided \$273 million funding to secondary and high schools to support the deployment and integration of educational technology into classroom instruction. Classroom Technology is the collection of software, hardware and, processes that facilitate learning (and teaching) and thus impact (mostly positively) the learner's attitude and performance (Govindasamy 2002; Khan 2000). Similarly, learner attitude is defined as the impact or influence of classroom technology on a student's disposition towards learning and this can be positive, negative, or neutral (meaning no change).

From September 2007 to September 2008, a University in Qatar (a country in the Middle East Gulf region) was fitted with classroom technology with the prime aim of creating an interactive and conducive learning environment. Within this context the issues that were considered pertinent in initial post-implementation stage, as far as learner attitude was concerned, were:

- experience with basic Information and Communications Technologies ICTs) and their effect on learner (Liaw, Huang, \& Chen, 2007).

- broadening of classroom technology initiated communications channels and its impact on learning and absorbing abilities of students (Urden \& Weggen, 2000).

- level of learning independence created through use of classroom technologies (Cuban, 1993).

- level of difficulty related to both the operational (know how to use) and situational (in working order) aspects of classroom technologies (Bannan-Ritland, Dabbagh, \& Murphy, 2000; Singh, 2000).

Consequently the prime focus of this study is on the introduction of an assortment of classroom technologies (i.e., a combination of audio-visual equipment and online systems) within a university (i.e., higher education) and their impact on the learners' attitude. According to a number of academics in the educational technologies field, through the implementation of educational technology student attitude tends to improve, and the students are also better prepared to enter and succeed in the digital workplace (Chen, Lee, \& Chen, 2005; Liaw, 2004). Similarly, many collaborative learning theories argue that human interaction is a vital ingredient to learning and classroom technologies tend to increase the bandwidth of face-to-face (especially written and gestural) communication avenues, which creates an exchange environment where information is shared and enriched through application of classroom technologies (Bharati, 2003; Liaw \& Huang, 2003). These views raise a number of questions; namely, Do classroom technologies create a platform for enhanced communications? Do classroom technologies provide new channels for information acquisition and exchange? Do classroom technologies help learner with selfdirected learning by accessing relevant materials on their own? With these questions in mind and forming the research objective, the investigation examined the impact of classroom technology (which included a combination of laptop, overhead projector, document camera, DVD player, speakers, video-conferencing facility, and in-class wireless internet access) on learner attitude. 
As exploratory research, two focus groups (one for male and one for female students) were conducted to identify the key variables of classroom technology-related learner attitude (see Table 1). The university student population is segregated into males and females. Hence genders are divided into two distinct campuses and are not allowed to mix. In order to obtain a balanced and representative view of the learners it was considered appropriate to conduct separate focus groups for male and female students. As the final data collection was done through a broadcasted survey (i.e., an e-mail, with attached questionnaire, was sent to the respondents) there was no need for the physical separation of male and female students (see Appendix, Audiovisual Technology Survey).

Exploratory research helped with the selection of key antecedents (i.e., ICT experience, Learner Independence, Enhanced Communications and Ease of technology use) and consequence (Individual learner attitude) that constituted the research model (see Figure 1).

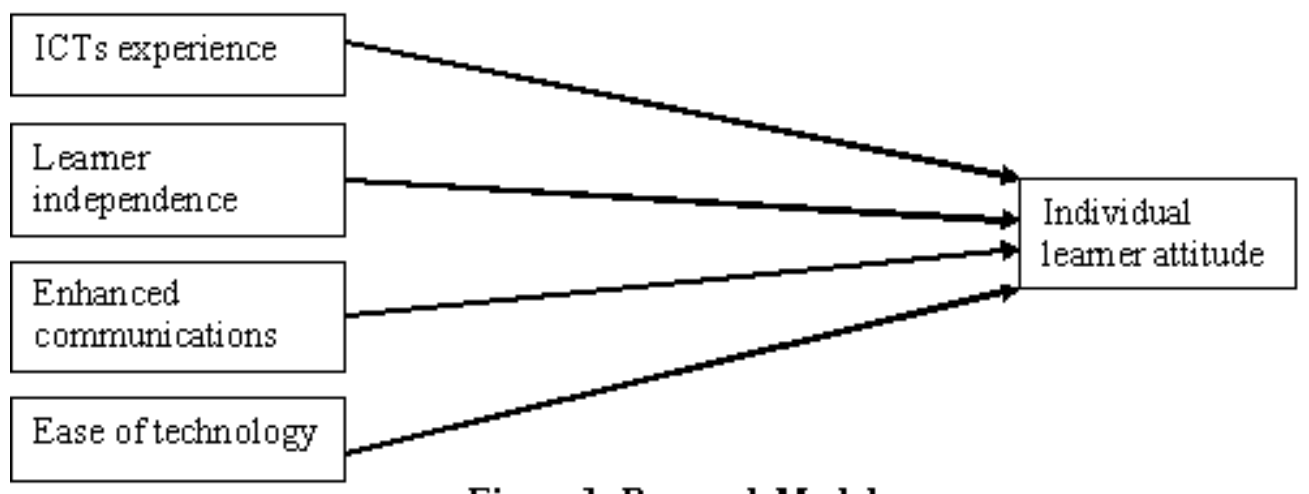

Figure 1: Research Model

\section{Literature Review}

Classroom learning within higher education involves different instruction contexts, practical activities, and variety of course assessments coupled with guidance and direction in the form of mentoring and teaching. Within this specific learning context, simulated and virtual environments (partly based on and driven by classroom technologies) provide the capability and means to create problem-solving groups and communities in which participants can gain knowledge and skills through interacting with other participants and different sources of relevant information. The use of classroom technologies tend to improve the quality of learning by involving learners in virtual and face-to-face exchange environments and by facilitating better access to educational resources such as internet and electronic library (Saade \& Bahli, 2005). Hence, university learning in digital space (and classroom technologies are part of it) can lead to enhanced learning experience largely due to opening up of student's environment (Mun \& Hwang, 2003).

Among many factors that can influence the extent of individual learning include factors such as student learning style (independent or dependent), learner channels of information acquisition and exchange, familiarity with information technology, and learner motivation (Buch \& Bartley, 2002). As far as learning is concerned, there are two major competing theories - objectivist (behavioral) and constructivist (cognitive) theory. Objectivists believe that knowledge exists outside the learner's mind and can be transmitted from teacher to student, whereas constructivists emphasize that knowledge is constructed in the mind of the learner as a consequence of working through real-world situations (Honebein, Duffy, \& Fishman, 1993). There is a belief that ICTs, particularly the Internet, support the constructivist environment. Hence researchers believe that classroom technology facilitates project-based, cooperative, interdisciplinary, and thematic learning 
(Manochehri \& Young, 2006). Furthermore educational technology tends to minimize the isolation of classrooms, thus breaking down traditional models of privacy. According to Massy and Zemsky (1995) technology enables self-paced learning with sensitivity to different learning styles and continuous assessment of student's progress.

Classroom technology can offer focused and clear instruction and hence can target specific needs of the learner. Furthermore, positive user attitude and user acceptance (based on previous experience of and interaction with ICTs) have been considered as critical factors that contribute to the successful application and implementation of classroom technologies (Venkatesh, Speicer, \& Morris, 2002). A common problem with implementation of new technologies is that sometimes in order to reflect an illusion of advancement and modernization, organizations jump on the bandwagon (without much thought) to show that they are keeping abreast of the technological progression (Govindasamy, 2002). This could result in waste of resources and disappointing outcome in terms of technology related performance. Hence the key question "How is technology going to impact the user?" needs to be asked so that efficient use of resources and effective use of technology is made. The proposed research will address this 'influence/impact' of classroom technologies on the user (attitude). The 'learner disposition' in terms of how he/she behaves within this 'technical environment' is the fundamental research premise of this study. Hence the evaluation and analysis of 'learner attitude' and how it is influenced and shaped by educational technology (i.e., control and adjustment of learning pace, amount of dependence on the instructor, utilization of remote learning technology and methods, levels of virtual and online interaction, etc.) will be investigated.

In context of Qatar, students represent a major part of the society, as individuals under the age of 25 forms around $45 \%$ of the total population. Within the last five years, these students have been exposed to ICTs, through initiatives such as digital government, public remote internet access, smart classrooms in most higher education institutions, and broader use of laptops in universities. This explosion of ICTs is changing a traditional and socially-centered nation at a tremendous rate. More specifically 'electronic and remote learning' is rapidly spreading in Qatar where (due to a very high GDP/Capital of over \$90,000) state-of-the-art educational and learning technologies are gracing primary and secondary schools, vocational and further education colleges, and universities. New equipment, latest software, premium hardware is being introduced rapidly. Government is actively driving this movement with a sizeable budget. But the question still remains, "How is the technology being utilized and how is it transforming the attitude of the learner?" Hence personal, social, and educational attitudinal elements need to be understood in order to create a conducive and appropriate learning environment where technology is one (although main) part of it.

Agreeing with Wang (2003) and Liaw (2004), learning behavior (and attitude is important part of this) needs a careful and detailed scrutiny to design and create socially, culturally, and educationally suitable environments. Furthermore, as per Rosenberg (2001), to develop a conducive elearning ambience, it is nearly essential to monitor and chart the attitude (e.g., motivations, distractions, likes, frustrations) of the learner. Through this 'analysis' educational technologies can be better directed to provide appropriate opportunities for enhanced learning through optimal consumption of implemented technologies. Additionally, one major misalignment as far as 'educational technology' and 'learner attitude' is concerned is the notion of 'practical and actual use' gap. Expectations are usually high in terms of benefits that should be provided by ICT's charged learning environments. However actual outcomes (in particular within different cultures) can be all together a different matter (Lowyck, Lehtinen, \& Elen, 2005). Hence this study endeavors to analyse this 'gap' through the lens of 'learner attitude.'

In addition, educational research argues that classroom technologies provide learners with elaborate and faster access to information, allow for more individualized and personalized instruction, and accommodate different learning styles. It is also reported that classroom technologies not 
only promote greater student involvement in learning but also generate more individual responsibility for learning (Wang, 2003). Appropriately used, classroom technology can help students acquire the skills they need to flourish and develop in complex and increasingly technical and knowledge-based economies (Ocker \& Yaverbaum, 2002; Shroff \& Vogel, 2009). Effective technology integration, into the classroom, should happen across the curriculum in such a way that it deepens and enhances the learning process. In particular, it should support three key components of learning: active engagement, participation in groups, and frequent interaction and feedback (Rosenberg, 2001). Effective technology integration is achieved when the use of technology is routine and transparent and when technology supports course objectives. For instance, learning through field projects while equipped with technology (such as a laptop, loaded with SPSS, for data collection and analysis) allows students to be intellectually challenged while providing them with a realistic experience and a snapshot of what the modern workplace looks like, which is where most students will end up eventually.

Hence a primary goal in utilizing a new medium of communication for educational delivery should be the identification of its impact on learning. A number of theorists (including Bostrom, Grant, Davis, \& Einerson, 1990; Brown, Collins, \& Duguid, 1989; Hmelo, 1993) have argued that the structure of typical traditional classrooms discourages the kinds of learning necessary for the 21 st century. It is time to reengineer the educational field by adopting new and innovative ways of creating effective and efficient teaching and learning atmospheres that will better prepare the human resource to enter the professional arena of the 3rd millennium. To achieve this transformation, a growing number of courses in higher and further education are being delivered using a variety of educational technology. These progressive approaches are found to be effective in positively impacting an increasing numbers of learners (Chang, Sung, \& Chen, 2001).

Several researchers (including Alexander, 1995, Fenwick, English, \& Parsons, 2001) argued that while implementing a new technology, educators should evaluate how and why students learn via the new technology in order to help with curriculum and instructional designs. Additionally, Manochehri \& Young (2006) stressed the importance of understanding how the new technology can affect learning. Hence another important reason for doing this research was perceived scarcity of research focusing on learner's attitude when dealing with new and sometimes unknown classroom technology. This research investigates issues (mainly techno-behavioral) that are likely to influence learner's disposition towards newly introduced classroom technologies.

\section{Research Model and Hypotheses}

In this section, we will first describe the research model, followed by the hypotheses. Two focus groups, one including 10 male students and one including 10 female students, were conducted to collect the perceptions of learners as far as initial utilization of classroom technologies and its impact on their learning attitude was concerned (see Table 1). Consequently a model was conceptualized that had four antecedents and one consequence. The research model is partially grounded in and reflects some components (i.e. ease of technology use and learner's attitude towards technology) of Technology Acceptance Model (TAM) (Davis, Bagozzi, \& Warsaw, 1989), which has been widely utilized to explain technology adoption within education (Jong-Ae, 2005). Especially TAM has been widely used in surveying user attitudes related to information technologies, which include classroom and educational technologies (Ma \& Liu, 2004; Saga \& Zmud, 1994). 


\section{Table 1: Perceptions of learners regarding classroom technologies}

\author{
Statements \\ Erbarces visual ard verbal experience \\ Clarityin teacher's explanation \\ Creates a virtual student \\ Integration of rulltiple learring soures \\ Helpe with illustration of complex examples \\ Stude rits can work at the ir owm pace \\ Irrporos level of inte rest in the subject \\ Stude rits car prepare lesorin artarue ard do extra research \\ Helps studerts to expess the ruse les nore cle arly in pesentation \\ He lps create ar interactive le aming emirorument \\ He lpe concentration as lecturer is not writing and speaking at the sarne tirne \\ Lecturer's body language becories more expesive
}

\% respondents
54
35
28
22
20
17
13
9
7
4
3
3

\section{H1: There is a positive relationship between ICTs Experience and Individual Learner Attitude}

ICTs Experience is defined as frequency and depth of interaction with basic software, such as MS Office, and internet search engines, such as Google and Yahoo, used for surfing and web browsing. Technology-driven individual learning is defined as the impact and influence of utilization of classroom technologies on student's attitude. Furthermore interaction with technology (in terms of frequency and diversity of use) can influence the attitude of students due to a potential positive (or non-negative) stance towards adoption of technology to support, supplement, enrich, and enhance their learning quantity and quality. Boghikian-Whitby and Mortagy (2008) found that students with prior ICTs experience performed better than those with no experience. Furthermore, positive user attitude and user acceptance (based on previous experience and interaction with ICTs) have been considered as critical factors that contribute to the successful application and implementation of classroom technologies (Venkatesh et al., 2002). Therefore, a positive relationship between ICTs experience and individual learner attitude is expected.

H2: There is a positive relationship between Learner Independence and Individual Learner Attitude

Independence is defined as self-management of studies by working on one's own initiative. Where a student takes more responsibility for his or her learning, technology can further complement this attitude by providing remote and ubiquitous access to learning resources (such as elibrary and Blackboard) and connecting students to other interest groups (such as fellow students, teachers, etc) to exchange information and discuss ideas. This freedom and flexibility (largely enabled and facilitated by omnipresent educational technology) when supplemented by face-toface communications and classroom teaching and consultation is likely to result in favorable learner attitude. Hence self-regulated learning where technology is one of the driving forces has a high probability of affecting the learner attitude positively (De Corte, 1990). In addition, educational research argues that classroom technologies provide learners with elaborate and faster access to information, allow for more individualized and personalized instruction, and accommodate different learning styles. It is also reported that classroom technologies not only promote greater student involvement in learning but also generate more individual control and responsibility for learning (Wang, 2003). 


\section{H3: There is a positive relationship between Enhanced Communications and Individual Learner} Attitude

Enhanced communications is defined as widened scope of information exchange through various ICTs-based and personal channels such as use of video and audio equipment, increased use of body language by instructor, face-to-face communication by the instructor by using voice projection and improved eye contact and body language. If we focus on technology induced communications, there are a number of examples of multimedia technologies (such as interactive animations and simulations, interactive environments for inquiry based learning, and virtual reality tools and programs) that can increase the 'sensory tenacity' of the user by enabling communication in various auditory and visual forms. Hence experiencing different types of electronic and non-electronic interactivity allows for a more active, flexible, self-controlled learning (Van Merrienboer \& Paas, 2003). Hence wide participation and utilization of various communication sources (vocal, animated, graphic, etc.) is likely to generate positive learner attitude. As a learner gets further involved in 'collaborative work' through utilization of different types of communications, this provides ample learning opportunities created through social linkages and knowledge sharing bonds. Hence involvement of different forms of communications channels (technology and non-technology based) are likely to amplify the individual learning by broadening the scope of information exchange. Hence a positive relationship between enhanced communications and learner attitude is proposed.

H4: There is a positive relationship between Ease of Technology use and Individual Learner Attitude

In using the classroom technology, 'operational' difficulty relates to know-how in terms of using the technology whereas 'situational' difficulty relates to the 'fitness status' (i.e., ready for use/in working order) of the equipment. Hence ease of use can be associated with two states: i) the learner is not ready and able to use the technology due to lack of experience and operational knowledge; ii) the technology (the equipment, the system) is not in a fit state for use. State (ii) could be due to permanent or transient faults such as loose connection, open circuit, faulty component, network down, or disturbed setting. Ease of use has a strong correlation with time window when it comes to in-session or in-class use of technology. In-class learning is temporally constrained (i.e., session of limited duration), and if the technology does not work 'right away' then the 'session plan' is disturbed and confidence and reliance on technology is shaken. Hence ease of technology use is expected to show a positive link with learner attitude.

\section{Research Methodology}

\section{Sample}

The sample was based on the QU students, both male and female, from different colleges and departments. The questionnaire was broadcasted, using the university e-mail network, to the students. Eight hundred (800) questionnaires were sent out for self-completion with clear instructions. A total of 178 questionnaires were returned. This represented a response rate of about $22 \%$ which is comparable to similar studies (Klass, McClendon, \& Gainey, 2002).

After taking out the unusable questionnaires, a total of 161 questionnaires were deemed suitable for further analysis. The test of non-response bias (i.e. comparing early and late respondents) was not necessary as all the data was collected in one phase. 


\section{Measures}

Table 2 lists all the items (seventeen in total) that formed the antecedents and consequence used in the research model.

\section{Table 2: Measures and item detaik}

\begin{tabular}{|c|c|}
\hline Mleasure & Items \\
\hline ICTs Experience & $\begin{array}{l}\text { Item } 1 \text { - Know edge and ability of the leamer to use basic ICTs } \\
\text { Item } 2 \text { - Use of intemet and e-mails to supplement leaming }\end{array}$ \\
\hline $\begin{array}{l}\text { Learner } \\
\text { Independence }\end{array}$ & $\begin{array}{l}\text { Item } 3 \text { - Proactive course inwolwement of leamer as a fesult of } \\
\text { utilizing classtoon technologies } \\
\text { Item } 4 \text { - Classroom technologies aiding leamer with lesson } \\
\text { preparation } \\
\text { Item } 7 \text { - Classroom technologies helping leamer to do more } \\
\text { work on its own } \\
\text { Item } 8 \text { - Classroom technologies helping leamer to control its } \\
\text { pace and speed of leaming }\end{array}$ \\
\hline \multirow[t]{3}{*}{$\begin{array}{l}\text { Enhanced } \\
\text { Communications }\end{array}$} & $\begin{array}{l}\text { Item } 9 \text { - Classroom technologies are futther stimulating } \\
\text { leamer's problem solving ability through enhancement of wisual } \\
\text { (image based) communication }\end{array}$ \\
\hline & $\begin{array}{l}\text { Item } 10 \text { - Classtoom technologies are futher stimulating } \\
\text { leamer's firoblem solving skills through enhancement of audible } \\
\text { (sound based) communication }\end{array}$ \\
\hline & $\begin{array}{l}\text { Item } 12 \text { - Leamer becomes more involved and interactive, } \\
\text { during sessions, when classnom technologies are used }\end{array}$ \\
\hline \multirow[t]{2}{*}{$\begin{array}{l}\text { Individual Leatriet } \\
\text { Attitude }\end{array}$} & 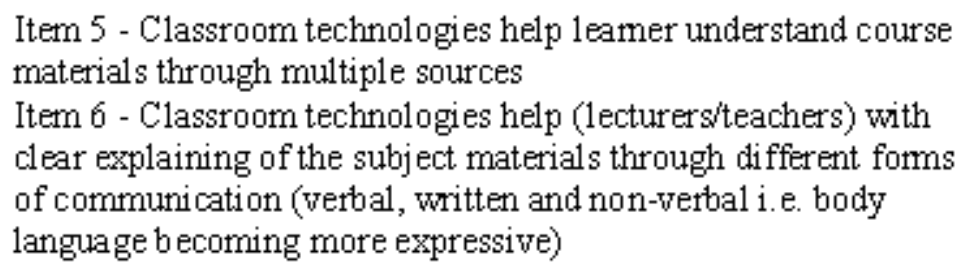 \\
\hline & $\begin{array}{l}\text { Item } 11 \text { - Classroom technologies improwe the learnitig frocess } \\
\text { of the indiwidual through multiple sources of stimulation } \\
\text { Item } 13 \text { - Classroom technologies create an effective classroom } \\
\text { enwironment through which concepts and id eas can be grasped } \\
\text { and exchanged more effectively and easily }\end{array}$ \\
\hline $\begin{array}{l}\text { Ease of technology } \\
\text { use }\end{array}$ & $\begin{array}{l}\text { Item } 14 \text { - I hawe to problem in operating the class foom } \\
\text { technologies } \\
\text { Item } 15 \text { - If there is something wrong with the equipment than } \\
\text { technical suppott is inmediately available } \\
\text { Item } 16 \text { - I do not need any trainifig to teach me how to use the } \\
\text { dassroom technologies } \\
\text { Item } 17 \text { - I find classroom technologies in full working order } \\
\text { whenever I want to use them }\end{array}$ \\
\hline
\end{tabular}




\section{Reliability, Validity and Regression Analysis}

Prior to being used for final data collection, all the measures were reliability and validity tested. Refer to Tables 3 (Descriptive statistics and reliability analysis), 4 (Correlation matrix) and 5 (Exploratory Factor Analysis). In addition, regression analysis (Table 6) was performed to evaluate the model pathways (i.e., proposed hypotheses). The regression analysis indicated a stable model with acceptable goodness of fit. All the items were based on 5-point Likert scales. The research model was tested using a self-completion questionnaire in English and Arabic.

Table 3: Descrip tive statistics and reliability analysis

\begin{tabular}{llll} 
Construct & Meari & SD & Choribach's a \\
\hline IT Experience & 3.71 & 0.965 & 0.631 \\
$\begin{array}{l}\text { Learner } \\
\text { Independence }\end{array}$ & 3.70 & 1.020 & 0.803 \\
$\begin{array}{l}\text { Enhanced } \\
\text { Communications }\end{array}$ & 3.69 & 1.000 & 0.746 \\
$\begin{array}{l}\text { Individual Learning } \\
\text { Attitude }\end{array}$ & 3.98 & 0.939 & 0.791 \\
$\begin{array}{l}\text { Ease of dassroom } \\
\text { technology use }\end{array}$ & 3.86 & & \\
\end{tabular}

Tah le 4: Correlation matrix

\begin{tabular}{|c|c|c|c|c|c|}
\hline Construct. & $\begin{array}{l}\text { Individual } \\
\text { Leaming } \\
\text { B ehavior }\end{array}$ & $\begin{array}{l}\text { IT } \\
\text { Expetience }\end{array}$ & $\begin{array}{l}\text { Learner } \\
\text { Independence }\end{array}$ & $\begin{array}{l}\text { Enhanced } \\
\text { Communications }\end{array}$ & $\begin{array}{l}\text { Ease of } \\
\text { dasstoonn } \\
\text { technology } \\
\text { use }\end{array}$ \\
\hline $\begin{array}{l}\text { Inidividual } \\
\text { Learnitig } \\
\text { B Ehaviot }\end{array}$ & 1 & & & & \\
\hline IT Experience & 0.218 & 1 & & & \\
\hline $\begin{array}{l}\text { Learner } \\
\text { Independence }\end{array}$ & $0.599 * *$ & $0.352^{* *}$ & 1 & & \\
\hline $\begin{array}{l}\text { Erihanced } \\
\text { Communications }\end{array}$ & $0.716^{* * *}$ & $0.317^{*}$ & $0.578^{* * *}$ & 1 & \\
\hline $\begin{array}{l}\text { Ease of } \\
\text { classtoon } \\
\text { techtiology use }\end{array}$ & $0.621^{* *}$ & $0.458^{* *}$ & $0.598^{* *}$ & $0.361 *$ & 1 \\
\hline
\end{tabular}

Wote: **orrelation is signific art at the 0.01 level (2-tailed)

* Comelation is significart at the 0.05 level (2-tailed) 
From the information presented in Table 3 we can see that the Cronbach's $\alpha$ value for all constructs is above 0.60 which is considered as a threshold value indicating acceptable reliability (Fornell \& Larcker, 1981; Hair, Anderson, Tatham, \& Black, 1998). The bivariate correlations (i.e., correlation matrix) of the constructs are presented in Table 4. The fact that none of the correlations approached the reliability values of the constructs is an indication of the discriminant validity. On the strength of the above evidence we are satisfied with the overall validity and reliability of the measures.

Table 5: Exploratory Fac tor Analysis

\begin{tabular}{lllll}
\multicolumn{5}{c}{ Comp onents } \\
\hline 1 & 2 & 3 & 4 & 5
\end{tabular}.

\begin{tabular}{|c|c|c|c|c|c|}
\hline Item 1 & .275 & 491 & .660 & .008 & .772 \\
\hline Item 2 & .472 & .540 & .383 & .330 & .136 \\
\hline Item 3 & .714 & -.026 & -124 & 407 & .698 \\
\hline Item 4 & .642 & .151 & -.293 & .283 & .251 \\
\hline Iten 5 & .664 & -.472 & - & .217 & 639 \\
\hline Item 6 & .672 & -.537 & .069 & -.042 & -352 \\
\hline Itenn 7 & .648 & .332 & -.262 & .214 & -.264 \\
\hline Item 8 & .719 & .244 & -333 & .074 & .129 \\
\hline Item 9 & .660 & .246 & -.144 & -547 & .224 \\
\hline Item 10 & .663 & .245 & -.060 & -.418 & -119 \\
\hline Item 11 & .721 & .063 & -.077 & -.315 & .308 \\
\hline Item 12 & .761 & -.373 & .318 & -153 & .672 \\
\hline Item 13 & .709 & -.381 & .403 & .062 & .280 \\
\hline Item 14 & .296 & -.451 & -.437 & .063 & 526 \\
\hline Item 15 & .340 & .596 & .706 & .213 & 481 \\
\hline Item 16 & .197 & .453 & .138 & 459 & 572 \\
\hline Item 17 & 390 & .112 & .281 & .127 & 502 \\
\hline
\end{tabular}

Cormporent 1: Irodividual Learrer Attiture

Component 2: ICTs Experience

Component 3: Leamer Iride pendence

Comporent 4: Enlariced Commuricatione

Cormpont 5 : Ease of clasionm techology use

It was considered useful to perform Exploratory Factor analysis (EFA) to test the fitness of items in terms of their association to a construct. Hence EFA was run in order to let the items load onto the constructs statistically. As a result of the EFA (as shown in Table 5 above), five components (constructs) were identified (represented by bold figures) and formed the exogenous and endogenous variables for the research model. 


\section{Results}

\section{Demographics}

Demographics related to the study included the gender, age, and college split are given in Table 6 .

Table 6: Sample breakdown (n-161)

Gender split

Age split

College split
Female: 103 Male: 58

71 (17-20 years); 87 (21-25 years); 3 (26-30 years)

Business \& Economics 87; Engineering 44;

Arts and Sciences 21; Sharia and Islamic

Studies 6; Pharmacy 3

Table 6 clearly indicates that there were far more female respondents than male respondents (i.e., ratio of almost 2:1). Similarly most of the respondents belonged to $17-25$ years old age group, displaying a rather young population. In terms of the college representation, a majority of the respondents came from College of Business and Economics followed by Engineering and Arts and Sciences.

\section{Frequencies}

The data related to frequencies of use are given in Figures 2, 3 and 4.

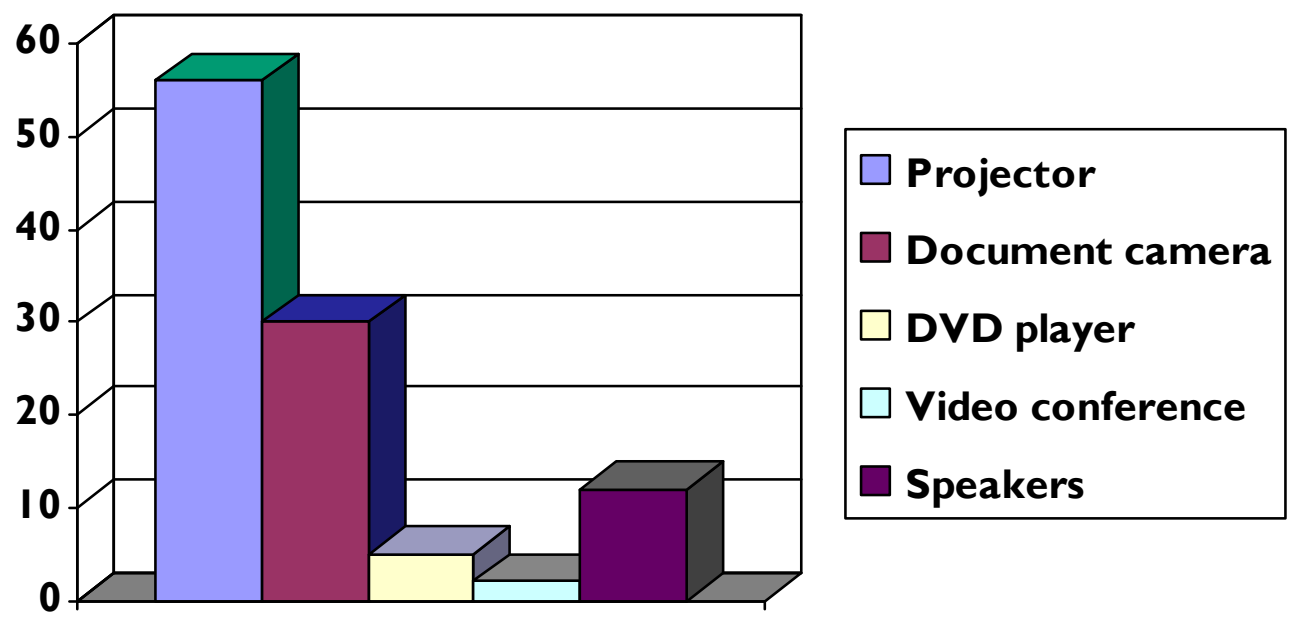

(Vertical axis represents number of users)

Figure 2: Classroom technologies used by faculty 

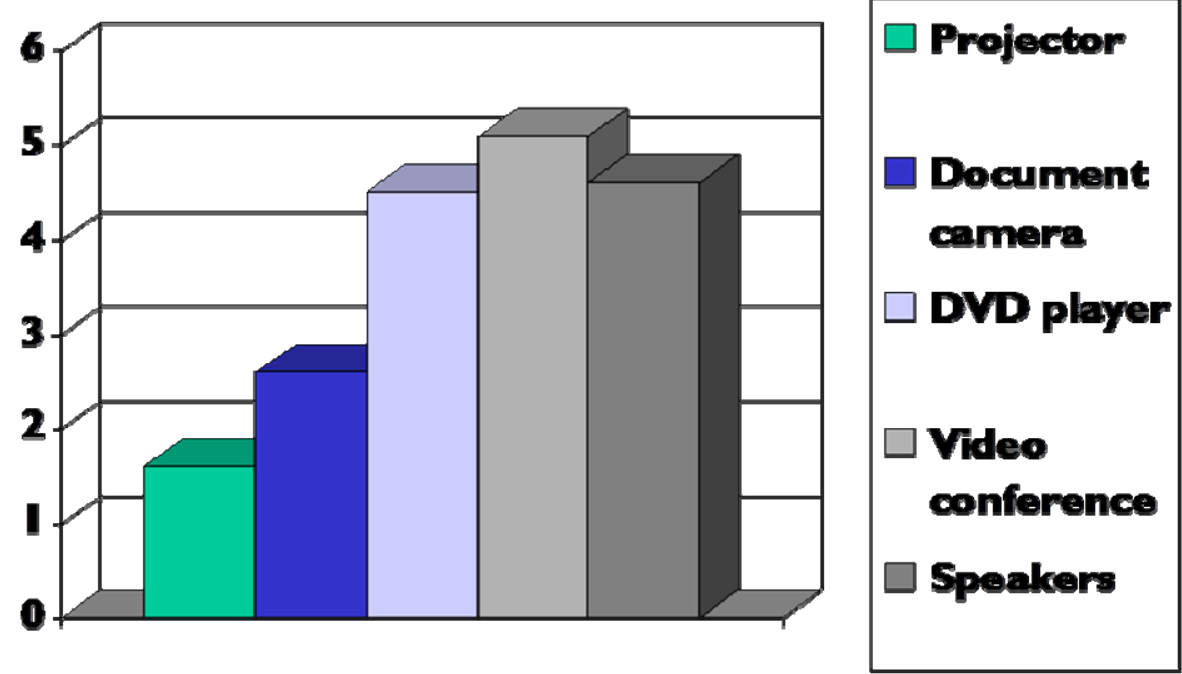

$1=$ most useful in learning; $6=$ least useful in learning

Figure 3: Student perception of usefulness of classroom technologies

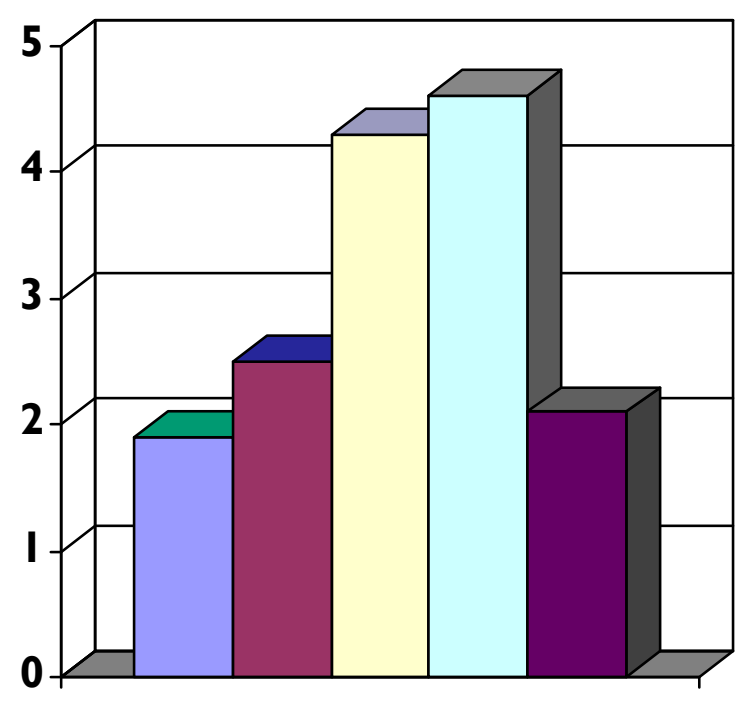

\begin{tabular}{|l|}
\hline Projector \\
$\square$ Document \\
camera \\
$\square$ DVD player \\
$\square$ Video \\
conference \\
Speakers \\
\hline
\end{tabular}

1=Daily; $2=$ Every other day; $3=$ Once a week; 4=Once

every two weeks; $5=$ Once a month

Figure 4: Classroom technology use by students

A common thread related to usage (both by faculty and students) and usefulness (students perception) seems to be that projector and document camera (basic technologies) are predominantly 
used with higher perceived usefulness whereas DVD and Video Conferencing are less frequently used and considered to be less useful.

\section{Hypotheses Testing and Pathway Analysis}

The outcome of the regression analysis is presented in Table 7.

Table 7: Regrexsion Analysis

\begin{tabular}{lllll} 
Model & t-malue & Sig & $\begin{array}{c}\text { Standardized } \\
\text { Coefficients }\end{array}$ & $\begin{array}{l}\text { Standand } \\
\text { Enror }\end{array}$ \\
\hline (Constant) & 3.538 & .001 & - & 0.371 \\
ICTs Experience & -.713 & .479 & -0.065 & 0.082 \\
Leamer Independence & 2.759 & .008 & 0.294 & 0.097 \\
E.tihanced Communications & 5.381 & .0010 & 0.566 & 0.095 \\
Ease of classtoom & 4.973 & .0010 & 0.513 & 0.086 \\
technology use & & & & \\
\hline
\end{tabular}

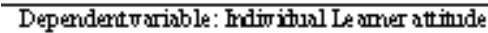

The research model was subjected to Multiple Regression Analysis (MRA) using SPSS 15. RSquare value (Co-efficient of variance) was .567 which implied that $56.7 \%$ of the model variation was explained by the three independent variables (i.e., ICTs experience, Learner Independence, and Enhanced Communications). In terms of the studied pathways, the MRA showed significant and positive relationships between Learning Independence, Enhanced Communications, and Ease of classroom technology use (t-values of $2.759,5.381$, and 4.973 respectively) and Individual Learner Attitude. However the association between ICTs Experience and Individual Learning Attitude was non-significant ( $\mathrm{t}$-value $=-.713$ ). With this outcome, in terms of the 'Outcome of the hypotheses' (Table 8), following can be concluded:

Table 8: Outcome of the hypotheses

\begin{tabular}{|c|c|c|}
\hline Proposed Hypotheses & Statistical Outcome & Hypotheses Status \\
\hline $\begin{array}{l}\text { IT Experience? Individual Learning } \\
\text { Attitude }(+)\end{array}$ & Non-significant & Rejected \\
\hline $\begin{array}{l}\text { Learner independence? Indiwidual } \\
\text { Leaming Attitude (+) }\end{array}$ & $\begin{array}{l}\text { Significant and } \\
\text { positive }\end{array}$ & Retained \\
\hline $\begin{array}{l}\text { Enhanced Communications? Individual } \\
\text { Leaming Attitude (+) }\end{array}$ & $\begin{array}{l}\text { Significant and } \\
\text { positive }\end{array}$ & Retained \\
\hline $\begin{array}{l}\text { Ease of dasstoom technology use ? } \\
\text { Individual Leaming Attitude }(+)\end{array}$ & $\begin{array}{l}\text { Sigtificant and } \\
\text { positive }\end{array}$ & Retained \\
\hline
\end{tabular}




\section{Discussion}

The major contribution of the study is that it is the first attempt to investigate the impact of classroom technologies in the initial phase of their implementation. This type of early analysis can help identify the developing attitudes of users, which can be an important finding as far as the future utilization of the classroom technologies is concerned.

The study outcome implied that use of classroom technologies, in the initial stages of introduction, does increase the capacity for self-directed learning through the availability, and creation, of further interaction and communications channels. However, prior ICTs experience seemed to have no impact on use of classroom technologies.

As instructors cannot always accommodate each student's need, it is important that several learning opportunities are provided. In this respect classroom technologies do present additional avenues through which learning can be generated and exchanged (e.g., accessing electronic library through laptop via wireless network anywhere and anytime, retrieving and placing learning materials on Black Board, etc). Furthermore, it is expected that when the learning experience is more relevant to the student, an increased level of individual user acceptance of information systems will result. Therefore, independence in learning (i.e., increased efficacy towards self managed and self-directed learning) is likely to occur (Compeaux, Higgins, \& Huff, 1999). The results also supported the findings of Barron and Orwing (1997) who indicated that technology enabled learners to learn at their own pace with continuous assessment, in contrast to the traditional way of teaching and learning.

In terms of enhancements of communications, it is likely to be enhanced (partly) due to the projection and display of information (mostly typed or written) by the classroom technologies (such as overhead projector, document camera, speakers, and DVD player). When this support is provided by the technology, the teacher has more time to concentrate on explaining and clarifying the material through gestures, eye contact, and such other body language displays. When interaction with peer groups, teachers, and online sources is improved it opens up the learner communication (at individual and group level) which facilitates opportunities for independent learning. Furthermore, the work of Romanov and Nevgi (2007) showed similar results. They reviewed the relationship between the use of multimedia equipment such as video clips and collaborative communication devices with learning attitude. They concluded that students who utilized multimedia were more energetic in using e-learning tools and achieved better course performance.

Ease of use in terms of equipment in a ready state of fitness during the class time affects the learner's attitude positively (Moon \& Kim, 2001). If learner is unable to operate the equipment (whether it is due to lack of operational knowledge or unavailability of timely technical support) the likely attitude towards classroom technology use will be negative.

It seems that previous experience with general ICTs does not impact uptake and utilization of classroom technologies for educational purposes. The probable reason for this (also supported by Passerini \& Granger, 2000) could be interest and motivation as a fundamental condition for technology-based learning rather than experience with ICTs.

\section{Practical Implications, Limitations, \& Future Research}

Training should be organized for the students to bring them to the same level of competence. It is quite probable that some students may be encountering difficulty in using the new classroom technology or technologies.

Technical support should be prompt and comprehensive especially during the early stages of classroom technology implementation as most of the problems are likely to occur during the introduction of new technology. 
In terms of limitations:

- Study is restricted to one institution therefore results should not be generalized.

- Quantitative research design may have created information gaps through which some of the relevant information may have slipped.

- $\quad$ Sample is unbalanced (i.e. more female than male respondents).

As far as the future research is concerned, research model needs to be expanded by including the following variables and investigating their impact on individual learner attitude:

- $\quad$ Relevant training

- $\quad$ Technical and maintenance support

Group analysis should be performed by cutting the data using the following variables:

- $\quad$ Gender of the learner

- College/department of the learner

- $\quad$ Age of the learner

The study should be replicated in a different learning environment to give it further validity.

\section{References}

Alexander, S. (1995). Teaching and learning on the World Wide Web. In R. Debreceny \& A. Ellis (Eds.), Aus web 95: Innovation and Diversity (pp. 93-99). New South Wales: Norsearch Limited.

Bannan-Ritland, B., Dabbagh, N., \& Murphy, K. (2000). Learning object systems as constructivist learning environments: related assumptions, theories, and applications. In D. A. Wiley (Ed.), The instructional use of learning objects [online version]. Retrieved June 18, 2005, from http://www.reusability.org/read/chapters/bannan-ritland.doc

Barron, A. E., \& Orwig, G. W. (1997). New technologies for education: A beginner's guide. Englewood, CO: Libraries Unlimited.

Bharati, P. (2003). People and information matter: task support satisfaction from the other side. Journal of Computer Information Systems, 43(2), 93-102.

Boghikian-Whitby, S., \& Mortagy, Y. (2008). The effect of student background in e-learning-longitudinal study. Issues in Informing Science \& Information Technology, 5, 107-126. Retrieved from http://proceedings.informingscience.org/InSITE2008/IISITv5p107-126Bogh483.pdf

Bostrom, R., Grant, N., Davis, W., \& Einerson, M. (1990). Characteristics of compulsive talkers: A preliminary investigation. Paper presented at the annual meeting of the International Communication Association, Dublin, Ireland.

Bratina, T. A., Hayes, D., \& Blumsack, S. L. (2002). Preparing teachers to use learning objects. Retrieved Jan 12, 2002, from http://technologysource.org/article/preparing teachers to use learning objects/

Brown, J. S., Collins, A., \& Duguid, P. (1989). Situated cognition and the culture of learning. Educational Researcher, 18, 32-42.

Buch, K., \& Bartley, S. (2002). Learning style and training delivery mode preference. Journal of Workplace Learning, 14(1), 5-10.

Chang, K. E., Sung, Y. T., \& Chen, S. F. (2001). Learning through computer-based concept mapping with scaffolding aid. Journal of Computer Assisted Learning, 17(1), 21-33.

Chen, C. M., Lee, H. M., \& Chen, Y. H. (2005). Personalized e-learning system using item response theory. Computers \& Education, 44, 237-255. 
Compeaux, D. R., Higgins, C. A., \& Huff, S. (1999). Social cognitive theory and individuals reactions to computing technology: a longitudinal study. MIS Quarterly, 23(2), 145-158.

Cuban, L. (1993). Computers meet classroom: Classroom wins. Teachers College Record, 95(2), 185-210.

Davis, F. D., Bagozzi, R. P., \& Warsaw, P. R. (1989). User acceptance of computer technology: A comparison of two theoretical models. Management Science, 35(8), 983-1003.

De Corte, E. (1990). Towards powerful learning environments for the acquisition of problem-solving skills. European Journal of Psychology of Education, 5(1), 5-19.

Fenwick, T., English, L., \& Parsons, J. (2001). Dimensions of spirituality: A framework for adult educators. Proceedings of the 20 annual conference of the Canadian Association for the Study of Adult Education, Université Laval, Quebec.

Fornell, C., \& Larcker, D. F. (1981). Evaluating structural equation models with unobservable variable and measurement error; Journal of Marketing Research, 18(1), 39-50.

Govindasamy, T. (2002). Successful implementation of e-learning pedagogical considerations. The Internet and Higher Education, 4, 287-299.

Hair, J. R, Anderson, R., Tatham, R., \& Black, W. (1998). Multivariate data analysis (5 ${ }^{\text {th }}$ ed.). New Jersey: Prentice Hall.

Hmelo, C. E. (1993). Learning in school and learning in life: An exploration of issues. Nashville, TN: Vanderbilt University Learning Technology Center.

Honebein, P. C., Duffy, T. M., \& Fishman, B. J. (1993). Constructivism and the design of learning environments: Context and authentic activities for learning. In T. M. Duffy, J. Lowych, \& D. H. Jonassen (Eds.), Designing environments for constructivist learning (pp. 87-108). Springer-Verlag.

Jong-Ae, K. (2005). User acceptance of web-based subscription databases: Extending the technology acceptance model. Doctoral Dissertation, Tallahassee, FL: The Florida State University.

Khan, B. H. (2000). A framework for web-based learning. Englewood Cliffs, NJ: Educational Technology Publications.

Klass, B. S., McClendon, J., \& Gainey, T. W. (2002). Trust and role of professional employer organizations: Managing HR in small and medium enterprises. Journal of Managerial Issues, 14(1), 31-48.

Liaw, S. S. (2004). Considerations for developing constructivist Web-based learning. International Journal of Instructional Media, 31(3), 309-321.

Liaw, S. S., \& Huang, H. M. (2003). An investigation of users' attitudes towards search engines as an information retrieval tool. Computers in Human Behavior, 19(6), 751-765.

Liaw, S. S., Huang, H. M., \& Chen, G.D. (2007). Surveying instructor and learner attitudes towards elearning. Computers \& Education, 49, 1066-1080.

Lowyck, J., Lehtinen, E., \& Elen, J. (2005). Students perspectives on learning environments. International Journal of Educational Research, 41, 401-406.

Ma, Q., \& Liu, L. (2004). The technology acceptance model: A meta analysis of empirical findings. Journal of Organizational and End User Computing, 16(1), 59-72.

Manochehri, N., \& Young, J. (2006). The impact of student learning styles with web-based learning (WBL) or instructor-based learning (IBL) on student knowledge and satisfaction. The Quarterly Review of Distance Education, 7(3), 313-316.

Massy, W., \& Zemsky, R. (1995). Using information technology to enhance academic productivity. Retrieved December 18, 2008, from http://www.educause.edu/nlii/keydocs/massy.html

Moon, J. W., \& Kim, Y. G. (2001). Extending the TAM for a World-Wide-Web context. Information \& Management, 38, 217-230. 
Mun, Y. Y., \& Hwang, Y. (2003). Predicting the use of web-based information systems: Self-efficacy, enjoyment, learning goal orientation, and the technology acceptance model. International Journal of Human-Computer Studies, 59, 431-449.

Ocker, R., \& Yaverbaum, G. J. (2002). Collaborative learning environments: Exploring student attitudes and satisfaction in face-to-face and asynchronous computer conferencing settings. Journal of Interactive Learning Research, 12(4), 427-448.

Passerini, K., \& Granger, M. J. (2000). A development model for distance learning using the Internet. Computers \& Education, 34, 1-15.

Romanov, K., \& Nevgi, A. (2007). Do medical students watch video clips in eLearning and do these facilitate learning? Medical Teacher, 29(5), 490-494.

Rosenberg, M. J. (2001). E-learning, strategies for delivering knowledge in the digital age. New York: McGraw Hill.

Saade, R., \& Bahli, B. (2005). The impact of cognitive absorption on perceived usefulness and perceived ease of use in on-line learning: An extension of the technology acceptance model. Information \& Management, 42(2), 317-327.

Saga, V., \& Zmud, R. (1994). The nature and determinants of IT acceptance, routinization, and infusion. IFIP Transactions A (Computer Science and Technology), A(45), 67-86.

Shroff, R. H., \& Vogel, D. (2009). Assessing the factors deemed to support individual student intrinsic motivation in technology supported online and face-to-face discussions. Journal of Information Technology Education, 8, 59-85. Retrieved from http://www.jite.org/documents/Vol8/JITEv8p059085Shroff416.pdf

Singh, H. (2000). Achieving interoperability in e-learning. Retrieved Oct 21 2002, from http://www.learningcircuits.org/2000/mar2000/singh.html

Urden, T. A., \& Weggen, C. C. (2000). Corporate E-learning: Exploring a new frontier. WR Hambrecht and Company Equity Research Report.

Van Merrienboer, J. J. G., \& Paas, F. (2003). Powerful learning and the many faces of instructional design: Towards a framework for the design of powerful learning environments. In E. De Corte, L. Verschaffel, N. Entwistle, \& J. J. G. Van Merrienboer (Eds.), Powerful learning environments: Unravelling basic components and dimensions (pp. 3-20). Oxford: Elsevier.

Venkatesh, V., Speicer, C., \& Morris, M. G. (2002). User acceptance enablers in individual decision making about technology: Towards an integrated model. Decision Sciences, 33(2), 297-316.

Wang, Y. S. (2003). Assessment of learner satisfaction with asynchronous electronic learning systems. Information \& Management, 41, 75-86.

Wiley, D. (2001). Peer -to-peer and learning objects: the new potential for collaborative constructivist learning online. Proceedings of the IEEE International Conference on Advanced Learning Technology. Madison, USA, 494-495. Retrieved May 16, 2009 from http://ieeexplore.ieee.org/stamp/stamp.jsp?arnumber $=00943992$ 


\section{Appendix: Audiovisual Technologies Survey}

January 2009

\section{Section 1: Demographics}

(Please highlight bold your answer/option)

Gender: Male Female

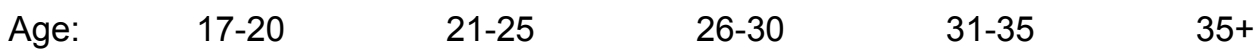

College

Department.

\section{Section 2: Confidence with technology}

(Please highlight bold your answer/option)

1. How often do you use a PC?

.......Every day

........Every other day

........ Once a week

....... Once every 2 weeks

........ Once a month

If option not covered above please state your response:

2. How often do you connect to Internet?

.......Every day

.......Every other day

........ Once a week

....... Once every 2 weeks

........ Once a month

If option not covered above please state your response:

3. Which application do you use on a regular basis?

........Word

........Excel

.......Power Point

.......Web browser

........Email

.......Black Board

If option not covered above please state 


\section{Section 3: Use of classroom technologies}

(Please highlight bold your answer/options)

4. When did you notice that new classroom technologies have been introduced in classrooms?

.........Not noticed yet

........1 year ago

.......6 months ago

3 months ago

If option not covered above please state

5. Which classroom technology(ies) do your teachers use?

.......Projector

........Screen

.......Document camera

.......DVD player

.......Video conference

.......Speakers

6. Please rank these classroom technologies from 1 (most useful in learning) to 6 (least useful). Please give a brief reason for why you find a particular technology useful in learning?

.......Projector

........Screen

.......Document camera

.......DVD player

.......Videoconference

.......Speakers

Reason for being useful in learning

In your course work, how often have you use the following classroom technologies?

a. Projector:

.......Every day

.......Every other day

........ Once a week

........ Once every 2 weeks

........ Once a month

Other 
b. Document camera

.......Every day

.......Every other day

........ Once a week

....... Once every 2 weeks

........ Once a month

Other.

c. DVD player

.......Every day

.......Every other day

........ Once a week

.......Once every 2 weeks

........ Once a month

Other.

d. Videoconference

.......Every day

.......Every other day

........ Once a week

.......Once every 2 weeks

........ Once a month

Other.

7. On a scale of 1-5, how would you rate the 'ease of classroom technology usage'?

1- Very Easy

2- Easy

3- Some difficulties

4- Difficult

5- Very difficult

If you have selected options 3,4 or 5 in the above question, which classroom technology/technologies do you find difficult to use and why 


\section{Section 4: Impact on learning}

Please indicate your response for each of the following statements by writing $\mathbf{X}$ in the rectangle.

\begin{tabular}{|c|c|c|c|c|c|}
\hline $\begin{array}{ll}\text { 1- } & \text { Strongly Agree } \\
\text { 2- } & \text { Agree } \\
\text { 3- } & \text { Neutral } \\
\text { 4- } & \text { Disagree } \\
\text { 5- } & \text { Strongly Disagree }\end{array}$ & 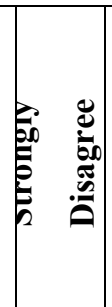 & 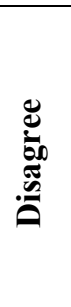 & z & 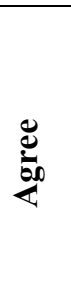 & $\frac{7}{200}$ \\
\hline I know how to use Classroom Technologies available in my class & & & & & \\
\hline I have used Classroom Technologies in enhancing my learning experience & & & & & \\
\hline $\begin{array}{l}\text { Classroom Technologies helped me in getting proactively involved with } \\
\text { learning on the course }\end{array}$ & & & & & \\
\hline Classroom Technologies helped me in preparing for the lesson/lecture & & & & & \\
\hline $\begin{array}{l}\text { Classroom Technologies helped me to understand the course material } \\
\text { through multiple sources of learning }\end{array}$ & & & & & \\
\hline Classroom Technologies help explaining the subject more clearly & & & & & \\
\hline $\begin{array}{l}\text { Classroom Technologies help me to become independent learners by doing } \\
\text { more work on my own }\end{array}$ & & & & & \\
\hline $\begin{array}{l}\text { Classroom Technologies help me to control my pace of learning by going } \\
\text { fast or slow }\end{array}$ & & & & & \\
\hline $\begin{array}{l}\text { Classroom Technologies help me to stimulate my problem solving skills } \\
\text { through visual experiences }\end{array}$ & & & & & \\
\hline $\begin{array}{l}\text { Classroom Technologies help me to further develop and stimulate my com- } \\
\text { munications skill }\end{array}$ & & & & & \\
\hline $\begin{array}{l}\text { My learning process has improvement since the implementation of Class- } \\
\text { room Technologies }\end{array}$ & & & & & \\
\hline Students are more interactive as the result of using Classroom Technologies & & & & & \\
\hline $\begin{array}{l}\text { Students can understand and grasp the concepts more easily and effectively } \\
\text { as result of using Classroom Technologies }\end{array}$ & & & & & \\
\hline I have no problem in operating the class room technologies & & & & & \\
\hline $\begin{array}{l}\text { If there is something wrong with the equipment than technical support is im- } \\
\text { mediately available }\end{array}$ & & & & & \\
\hline I do not need any training to teach me how to use the classroom technologies & & & & & \\
\hline $\begin{array}{l}\text { I find classroom technologies in full working order whenever I want to use } \\
\text { them }\end{array}$ & & & & & \\
\hline
\end{tabular}

Please save in your local disk and e-mail the completed doc file to me at:

\section{Thank you for your support and co-operation.}




\section{Biographies}

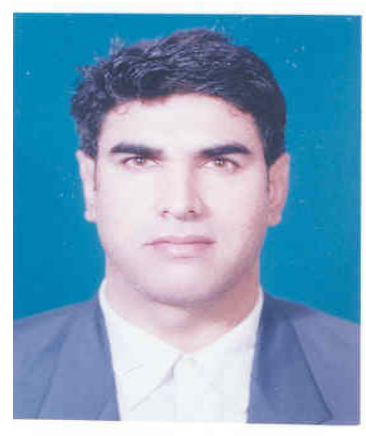

Nick-Naser Manochehri received his Ph.D. in Applied Technology from the University of North Texas, USA - 2001. His Ms. in Software Engineering and bachelor degree in Computer Science. He has several years of industrial experience as a software developer and senior instructor in the area of IT at SBC Communications Inc. in Dallas Texas. He also worked as an assistant professor in the department of IS at SQU in Oman. He is currently an assistant professor in the college of Business and Economics, department of Accounting \& Information Systems at the Qatar University. His research area of interest includes: IT, TQM, e/mobile Commerce, e-learning \& educational Technology.

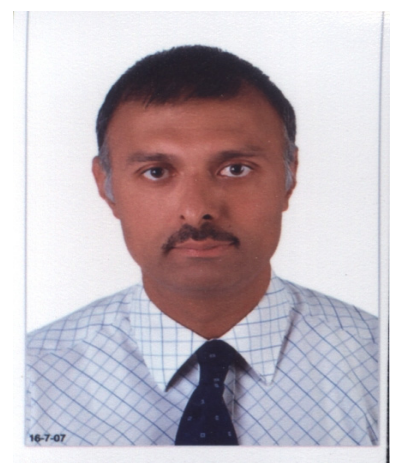

Khurram Sharif is an Assistant Professor of Marketing in College of Business \& Economics at Qatar University. He is also a Marketing Research Consultant and has worked with a number of educational, pharmaceutical and retail organizations on a variety of projects. His current research interests include marketing research design and methodologies, benchmarking sales force performance, category management practices in the Middle East, customer experience management, educational technologies and adult learners and managing SME business-to-business relationships. 